\title{
UPDATING THE MULTIDIMENSIONAL RELATIONSHIP TO INFORMATION IN SCHOOL ENVIRONMENT
}

\author{
Maja Gržina Cergolj \\ Basic School Lucija, Portorož, Slovenia
}

\begin{abstract}
The $21^{\text {st }}$ century announces the launch of many changes in getting and giving information. The cyber era requires the ability of managing different skills as well as meaningful integration with the past. In fact, the present deals with the management of multidimensional communications and requires lifelong training and readiness for change. Transliteracy as the ability to write, read and interact across a range of platforms, tools and media, allows the fusion of the cyber era peculiarities with the sense of belonging to the past. It indicates the upgrading of literacy and operates on the level of individual attention. It is anchored in the form of deep learning, regardless of the sense which enabled it to flow. The multidimensionality provides a holistic view of information and a critical elimination of the irrelevant issues. It is also a means by which a teacher can achieve better results in the classroom, if he finds the appropriate channeling of attention. It does not mean the absolute transition into the information society, but only the management of yesterday, today and tomorrow. It means collaboration, management and education for the literacy of the future.
\end{abstract}

Key words: cyber era, deep learning, lifelong learning, transliteracy.

\section{Introduction}

The $21^{\text {st }}$ century announces the advent of the cyber era which focuses on the connections between energy and information to produce knowledge (Frau-Megis, 2012, p. 15). In the cyber era we gradually saw a new context of collaboration between media and information literacy which, by themselves, led to more complex skills that, at the same time, required new knowledge for users and new forms of literacy (Frau-Megis, 2012, p. 15).

The knowledge society actually wonders if we can handle this transformation. Can we maintain the authenticity and legacy of the $19^{\text {th }}$ century and upgrade it with the skills of cyber era? Are we able to understand the messages of our own children, without falling into a digital divide and feel digitally misunderstood, excluded and even got played?

During the Transliteracies Research Project in 2005 led by Professor Alan Liu at the Department of English at the University of California in Santa Barbara, the term transliteracy was created. In the context of the Research Project of e-competent citizen of Slovenia (Be ter, 2012) the definition of transliteracy was enriched with the definition of Sue Thomas (2007) as "the ability to read, write and interact across a range of platforms, tools and media from signing and orality through handwriting, print, TV, radio and film, to digital social networks" (Thomas et al., 2007). The definition as such suggests the cooperation between 
literacy and the holistic understanding of messages. The advent of Internet and new forms of information and communication technologies (ICT) has led to the necessity for the acquisition of e-competences and their effective use while, in the academic world, theorists justify the necessity for a re-definition of the concept of literacy as we have known it so far as the ability to read and write (Be ter, 2012, p. 5).

The fact is that it is the progress that dictates the tempo and the range of transliteracy and requires of an individual to embark on a lifelong journey of education. In the context of education, this phenomenon is particularly relevant as it offers us the possibility of understanding the world of children. Thus we can get closer to them and adapt the lecture to their attention. Frau-Megis (2012) says that we are able to define transliteracy as the horizon of a process full of possibilities, which is connected to the computer, information, and communication science only because we are aware of the centralization and the inevitability of literacy (Frau-Megis, 2012, p. 21).

As already mentioned above, the digital divide is the only factor that can give us a sense of misunderstanding, exclusion or a sense of being manipulated. Reducing the digital divide in the population might be the contribution of transliteracy that like in the society itself can create the conditions of inclusion in the school as well. Cyber life requires its own form of inclusion which should be adapted to the number and age of the population that believes or not in lifelong learning. Research results (Bešter, 2012) place Slovenia above the EU average in the obtaining e-competences (formal, informal, self-directed), lacking behind only in the education in organizations. And here arises the fact that the performance of companies and their competitiveness depends on many factors but the knowledge about new technologies often represents a key advantage (Be ter, 2012).

The purpose of this study is to find out how much transliteracy is already in use, as a new form of literacy.

\section{Methodology of Research}

By definition transliteracy is the re-definition of the concept of literacy that is known today as the ability to read and write (Be ter, 2010-2012), so in the empirical part we put forward research questions with statements that are not exclusively related to information literacy, but to everything that can be related to literacy in its entirety, with all that captures our attention and which can be interpreted as a message.

The survey was in the form of a questionnaire. It was conducted with 54 students, aged 13 to 14 years, at one of the elementary schools in the bilingual area of Slovenian Istria. They are asked about their attention and their relation to ICT such as their access to books, newspapers and other sources that are associated with the classical definition of literacy. The survey aims to explore the existing level of transliteracy and to update the existing teaching methods which include the learner's attention in the learning process. The whole ability to understand information is a way to upgrade the teaching that leads to the beginning of a process of deep learning.

Both theoretical and empirical work helped identifying new dimension of literacy, how they differ and how they interconnect in a multi-dimensional whole. The research results are described in the following sections and provide partial guidance for the implementation of the transliteracy phenomenon in the scenario of modern teaching to contemporary students in the cyber age. 
Students responded to a questionnaire with five questions with given answers:

1) What is closer to you?

2) What would you choose?

3) What do you notice first?

4) What do you prefer reading?

5) Which application do you use most?

There are only five questions, because the educational program should not be interrupted for more than a few minutes.

The respondents were able to choose only one answer and were not separated by gender. Questionnaires were resolved independently in a quiet environment and without any help. The data have been entered manually and subsequently computer processed with a free app SurveyMonkey. It is online survey software. It makes it easier than ever to create survey questionnaires for learning about anything. With this online survey the tabulating results were found out much more quickly.

\section{Results of Research}

The first question was used to determine which medium is the most relevant to the students. This question was answered by 51 respondents and skipped by 3 . The Internet was expected at the first place, followed by the television and the book, while the radio and the magazine have reached exactly the same ratio. It is interesting that none selected the journal.

The first (1) question is: What is closer to you?

Table 1. The results of the first (1) question.

\begin{tabular}{|c|c|}
\hline Answer Choices & Response rate in \% \\
\hline TV & 21.57 \\
\hline Internet & 56.86 \\
\hline Radio & 5.88 \\
\hline Magazine & 5.88 \\
\hline Newspaper & 0 \\
\hline Book & 9.80 \\
\hline Total & 100 \\
\hline
\end{tabular}

From the given results, we find that the students' attention is more focused on Internet, television and books. This is interesting information for the classroom work and work at home: we have to focus on the exploratory learning in these media. Among others, the present results are also a sign of active transliteracy, because the search of relevant information is tied to a combination of literacy, which are related to the information literacy and literacy in the past.

Results also show us not only the statistics of the current media, but also the historical development of media that coincides with the growth and the actuality of use. 
In the second question, the respondents were asked what they would choose if they could choose between a book, a mobile phone and an iPad. This question was answered by 53 respondents, 1 skipped this question. It was expected that the technology will come in the first place. As we can see in the table below the iPad is in the first place, followed by a cell phone and a book.

The second (2) question is: What would you choose?

Table 2. The results of the second (2) question.

\begin{tabular}{|c|c|}
\hline Answer Choices & Response rate in \% \\
\hline Book & 9.43 \\
\hline Cell Phone & 35.85 \\
\hline iPad & 54.72 \\
\hline Total & 100 \\
\hline
\end{tabular}

The results show us that the students' attention, even in this choice, was oriented into the information technology. For the classroom work and work at home it is, again, a sign of active transliteracy, because all three choices require peculiar literacy, e-skills and connecting skills.

Even in this case the historical development of media coincides with the actuality of use. From the respondents, therefore, are expected multidimensional skills that involve their attention and allow them to consolidate the deep knowledge.

In the next issue we were interested in what attracts the attention of the media, which is not bound by the information age and information literacy but, in a classic, not re-defined form of literacy. This question was answered by 53 respondents, 1 skipped this question. The respondents were asked what they firstly saw in the book. The most frequent answer was the title of the book, the number of pages, the color, and only at the end the author.

The third (3) question is: What do you notice first?

Table 3. The results of the third (3) question.

\begin{tabular}{|c|c|}
\hline Answer Choices & Response rate in \% \\
\hline Color & 18.87 \\
\hline Title of the book & 52.83 \\
\hline Author & 3.77 \\
\hline Number of pages & 24.53 \\
\hline Total & 100 \\
\hline
\end{tabular}

Through this question, we studied how the attention is directed to the use of traditional literacy. The respondents firstly choose the title of the book, because through this information, they can learn something about the content and, for many, it is crucial for the choice. The second place is reserved for the number of pages. It expresses the preference for a longer/shorter reading. The color of the book is the fact that points to the situation of 
the society, which currently pays great attention to the appearance and attractiveness. An interesting fact is the author, who remains in the last place, despite the fact that the book without the author would not have been written. It also reminds teachers to pay attention to the title of the book, its volume and its appearance.

The fourth question relates to the reading. Pupils were asked what they like to read. This question was answered by 51 respondents, 3 of them skipped this question. In the first place they put the book, followed by the article, the blog and the e-book. It is interesting that, despite the information society, the book is still in the first place. In the second place is placed the article, but this information is incomplete, because we did not indicate the type of the article (magazine, web, newspaper etc.), so in this case, it is difficult to define the validity of the information. It is more interesting, that the blog and the e-book are not well known. At the same time, this information indicates that respondents do not have a lot of contact and are, therefore, not well known.

The fourth (4) question is: What do you prefer reading?

Table 4. The results of the fourth (4) question.

\begin{tabular}{|c|c|}
\hline Answer Choices & Response rate in \% \\
\hline Book & 45.10 \\
\hline Blog & 13.73 \\
\hline Article & 33.33 \\
\hline e-Book & 7.84 \\
\hline Total & 100 \\
\hline
\end{tabular}

There is an interesting look at the big advantage of classical, not re-defined literacy against the information technologies. Certainly it is not in line with the expectations of the Information Age and is also a fact that confirms the connection to the classical literacy. The data justifies the coexistence of different literacy, but also requires from the user the ability to understand the messages from all forms of media. In fact, it is difficult to expect that the classic literacy is permanently replaced with the cyber-innovations since the formation of the past is supported by an absolute and a centuries-old tradition of reading books.

With the last question we want to know which application is most used. This question was answered by 44 respondents and skipped by 10 . We can see the absolute advantage of the social network Facebook. The information is relevant, because the question is about the usage. The resulting percentage also means that here is also included the knowledge of use of Facebook. In the second place is Twitter, followed by the application WhatsApp.

The fifth (5) question is: Which application do you use most? 
Table 5. The results of the fifth (5) question.

\begin{tabular}{|c|c|}
\hline Answer Choices & Response rate in \% \\
\hline Facebook & 84.09 \\
\hline Twitter & 9.09 \\
\hline WhatsApp & 6.82 \\
\hline Total & 100 \\
\hline
\end{tabular}

\section{Discussion}

The purpose of the answers to all five questions was to determine how much transliteracy is already in use, as a new form of literacy, in the final three years of primary school. The students' answers, about the different media they use, indicate the upcoming change in relation to the understanding of information.

Updates of knowledge are global, such as transliteracy. It is actually the answer of the society on understanding the current time, which does not require us to eliminate the traditional media. They represent a part of us and are a part of the historical development of mankind. The coexistence of different literacies suggests an upgrading of teaching methods in conjunction with technological progress. As Frau-Megis said (Frau-Megis, 2012, p. 15) in the cyber era we gradually saw a new context of collaboration between media and information literacy. The knowledge society is fast and unpredictable. With the support of daily upgrade the forthcoming information age suggests changes which include the transliteracy skill.

The concept of transliteracy covers all existing literacies, media and platforms. It could be said, that it is a holistic concept that provides a view and an understanding of science and its development. It hides connections between data, learning and knowledge. The content of the concept is also related to all-inclusive globalization that is changing the world, in terms of people and of environment.

The future envisages a multidimensional view of knowledge and above all how we accept it, process it (Frau-Megis, 2012, p. 17) and maintain it. In the context of education transliteracy as the future of literacy, is the literacy that leads students to the formation of the connecting and blended learning. In doing so, the teacher has the leading primary role. He must focus on the multimodality of the medium and adjust the pupil's attentions (book title, book color, number of pages, social network, technology, etc.). This is a relevant fact that the future solutions regarding of how to teach students are sought by children themselves, thus taking into account their values and the teacher's lifelong education leads, which should lead to high-order skills.

\section{Conclusions}

The survey shows to what extent the progress of science has resulted in the information age and also how much connections we have maintained with the past by still preferring a printed book to an electronic media. We can not ignore the relevance and popularity of 
social networks, which do not have only communication-information function, but also the possibility to use it for educational purposes, mainly because of their popularity among young people. Channeling information online and connecting it with a book, TV, telephone, posters and other media is a sign of transliteracy in progress.

The main educational added value of this research is the role of the teacher that is changing, from moderator in transliterary to mediator between information and media. Guiding children to connect and use a variety of tools may be difficult and it can also be the cause of misunderstandings in the classroom or learning failures because transliteracy does not occur to the same extent in teachers and in students. Transliteracy just updates the multidimensional relationship to information in school environment.

\section{Acknowledgments}

The author acknowledges the support of the Ministry of Education, Science and Sport of Republic of Slovenia and European Social Fund in the frame of the Project: "Innovative pedagogy 1: 1 in the light of competences of the 21st century" on Faculty of Natural Sciences of University of Maribor.
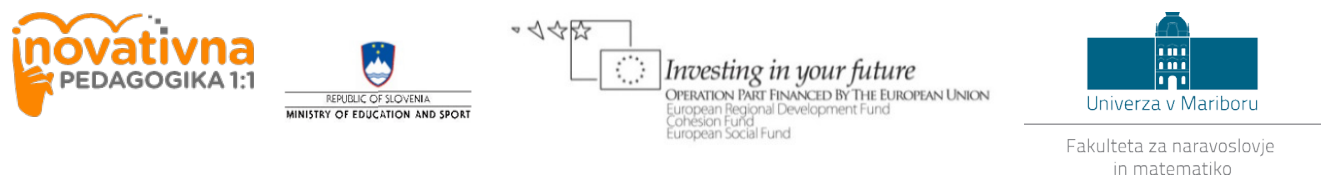

\section{References}

Bauman, Z. (1998). Globalization. The human consequences. New York: Columbia University Press.

Jenko, M., Guna, J., Kos, A., Pustišek, M., Bešter, J. (2012). Ekosistem podpore pri pridobivanju IKT veščin in znanj za starejše. Retrieved from http://www.mizs.gov.si/fileadmin/mizs. gov.si/pageuploads/Informacijska_druzba/pdf/EKDS_porocilo-V2-1021.pdf

Frau-Megis, D. (2012). Transliteracy as the new research horizon for media and information literacy. Medijske tudije: Media Studies, 3 (6), 14-26. Retrieved from http://hrcak.srce. $\mathrm{hr} /$ index.php?show=toc\&id_broj=7793

Facebook: Statement of rights and responsibilities (2014). Retrieved from https://www.facebook.com/legal/terms

Survey Monkey: Free online survey software \& questionnaire tool (1999 - 2014). Retrieved from https://www.surveymonkey.com/

Thomas, S., Joseph, C., Laccetti, J., Mason, B., Mills, S., Perril, S., Pullinger, K. (2007). Transliteracy: Crossing divides. First Monday, 12 (12). Retrieved from http://firstmonday.org/ article/view/2060/1908

Thomas, S. (2005). Transliteracy - reading in the digital age. The Higher Education Academy - Online Newsletter. Retrieved from http://www.english.heacademy.ac.uk/explore/publications/newsletters/newsissue $9 /$ thomas.htm 
2014, Nr. 2 (17) ISSN 2029-1922

\section{Maja Gržina Cergolj}

PhD Candidate, Librarian, University of Primorska \& Basic School of Lucija, Fazan 1, 6320

Portorož, Slovenia.

E-mail: maja.grzina@gmail.com 